\title{
IMPLEMENTING THE PACIFIC ISLANDS REGIONAL OCEAN POLICY: HOW DiFFICULT IS IT GOING TO BE?
}

\author{
Dr Laurence Cordonnery*
}

\begin{abstract}
This article discusses the challenges facing the Pacific region in implementing the Pacific Islands Regional Ocean Policy (PIROP), which aims to ensure sustainable use of the Pacific Ocean's resources for the future. The author outlines some of the particular issues confronting Pacific Island countries, and the need for a more collaborative approach to ocean management.
\end{abstract}

The five guiding principles of PIROP are then discussed in turn. These include: improving our understanding of the ocean; the sustainable development and management of the ocean's resources; maintaining the health of the ocean; promoting the peaceful use of the ocean; and creating partnerships and promoting cooperation. Issues such as the protection of traditional knowledge in relation to the ocean, and the need to preserve the integrity of the Pacific's ecosystems, are highlighted.

The Pacific Islands Regional Ocean Policy (PIROP) ${ }^{1}$ was produced by the Marine Sector Working Group of the Council of Regional Organisations in the Pacific, upon a request from the Pacific Islands Forum leaders in 1999. It is the first attempt in the world to adopt such a policy framework at an oceanic scale. ${ }^{2}$ The overall goal of PIROP is to "ensure the future sustainable use of our ocean and its resources by Pacific Islands communities and external partners". ${ }^{3}$ Although not legally binding, PIROP provides a framework for the formulation and implementation of sustainable development in the region. It is expected to provide the basis for articulating future national ocean

* Visiting Fellow, East-West Center, Hawaii.

1 Pacific Islands Regional Ocean Policy (Brochure, Marine Sector Working Group, Council of Regional Organisations in the Pacific, Pacific Islands Forum Secretariat, Suva, 1999) available at $<$ http://www.spc.int $>$ (last accessed 2 June 2005).

2 Worldwide, Canada and Australia are currently the only two countries that have adopted a national ocean policy. The European Union is also in the process of adopting a regional policy for its oceans.

3 Pacific Islands Regional Oceans Policy, above n 1, art 27. 
policies and to harmonise national and regional actions for its implementation. While endorsing the Policy, Forum leaders have called for follow up actions from the region and individual countries. The Pacific Islands Regional Oceans Forum held in Fiji in February 2004 was the first step to envisage practical ways of implementing the Policy. This article will discuss the issues raised by the implementation of PIROP at both regional and national levels. However, before embarking on a detailed policy analysis, it is essential to highlight the significance of PIROP as a step forward in the regional context of cooperation on ocean matters that is unique to Pacific Island countries (PICs).

\section{COOPERATION AS A SURVIVAL STRATEGY FOR PICS}

Pacific Island countries are known to be ecologically fragile and vulnerable to natural disasters. Their small size, limited land resources, geographic dispersion and isolation from markets, places them at a disadvantage economically and prevents economies of scale. Indeed, one of their specificities is the reliance on a subsistence economy in parallel to a developing import-dominated cash economy. This, in turn, explains the major importance of coastal resources to local communities since fish and shellfish from inshore waters are the primary source of protein available. In so far as offshore resources are concerned, the Western and Central Pacific Ocean provides the habitat for the world's largest and most valuable tuna resources, contributing over 50 per cent of the world 3.4 million tonnes of catch. ${ }^{4}$ According to the Secretariat of the Pacific Community, the exclusive economic zones (EEZs) of PICs yield 78 per cent of the Western and Central Pacific Ocean tuna catch, ${ }^{5}$ with an estimated value of US\$1.3 billion. ${ }^{6}$ Given the limited economic development options available, the importance of tuna resources and their exploitation to the economic security and sustainable development of PICs are considerable and cannot be overstated. PICs have traditionally exploited tuna resources for local consumption. However, artisanal fisheries, in comparison with industrial fishing activities undertaken by Distant Water Fishing Nations (DWFNs), represent less than 10 per cent of the total tuna catch. The negotiation of access agreements with DWFNs (mainly the United States, Japan, Taiwan, Korea and China) has therefore been the main strategy sought by PICs to obtain benefits from the foreign exploitation of tuna stocks present in their EEZs. Created in 1979, the Forum Fisheries Agency (FFA) has been mandated to promote regional cooperation and co-ordination amongst PICs in the management, conservation, legislation and fisheries policies for the tuna resources of its member countries. FFA has also played a pivotal role in the elaboration of a regional regulatory framework for ensuring the long-

$4 \quad$ T A Lawson (ed) Tuna Fishery Yearbook 1998 (Oceanic Fisheries Programme, Secretariat of the Pacific Community, Noumea, 1999).

5 A D Lewis "The Status of Pacific Tuna Stocks: The Interaction of Biological, Boundary and Legal Issues in the Conservation and Management of Highly Migratory Species" (Pacem in Maribus XXVII Conference, Suva, 7-12 November 1999).

6 G Van Santen and P Muller Working Apart or Together: The case for a Common Approach to Management of the Tuna Resources in Exclusive Economic Zones of Pacific Island Countries (Pacific Islands Discussion Paper Series, Number 10, The World Bank, Washington DC, 2000). 
term sustainability of tuna resources involving all stakeholders, including DWFNs. This long series of dialogue between FFA member states and DWFNs lead to the adoption of the Western and Central Pacific Fisheries Convention (WCPFC) 7 in Honolulu, in 2000. It is worth noting here that the WCPFC is the first regional outcome of the 1995 Agreement for the Implementation of the Provisions of the United Nations Convention on the Law of the Sea relating to the Conservation and Management of Highly Migratory Fish Stocks,${ }^{8}$ which specifically recommended the worldwide establishment of regional institutional arrangements between coastal states and harvesting states in the management of highly migratory fish stocks. Another illustration of regional coordination can be found in the continued support of the Secretariat of the Pacific Community as a provider of scientific advice in the management of tuna stocks. ${ }^{9}$ Other regional organisations, such as the South Pacific Regional Environment Programme (SREP) run training programmes and workshops to facilitate the implementation of various international and regional legal instruments linked to ocean governance, ranging from marine biodiversity conservation to the trans-boundary movement of hazardous wastes. Similarly, the South Pacific Applied Geosciences Commission provides technical assistance to its member states on maritime boundary delimitation issues and acts as the depository for marine scientific research data and information for the Pacific Islands. The University of the South Pacific, which caters for the higher education needs of its twelve member countries, is the main provider of training through its marine affairs programme.

\section{THE NEED FOR A REGIONAL OCEAN POLICY}

Despite the regional cooperation achievements described above, management of ocean issues at national and regional levels remains largely sectoral in nature. An integrated approach to ocean management is required at both national and regional levels to address cross-cutting issues and avoid duplication of activities. Collaboration among regional organisations certainly needs to be strengthened but, as membership is not uniform, disparities remain in the delivery of programmes. This is precisely why the geographical scope of the PIROP coincides with the broadest of all regional organisations, that of SREP membership, which includes twenty-two PICs and territories and five metropolitan countries. ${ }^{10}$ National capacities, infrastructure development and availability

$7 \quad$ The full name of this Convention is: Convention for the Conservation and Management of Highly Migratory Fish Stocks in the Western and Central Pacific Ocean (5 September 2000). The text of the Convention is available at: $<$ http://www.ocean-affairs.com/convention.html $>$ (last accessed 3 November 2005).

8 See for example Adam Langley and others The Western and Central Pacific Tuna Fishery 2003: Overview and Status of Stocks (Oceanic Fisheries Programme, Tuna Fisheries Assessment Report No 6, Secretariat of the Pacific Community, Noumea, 2005).

9 See the Secretariat of the Pacific Community "Ocean Fisheries Programme" $<$ http://www.spc.int/OceanFish > (last accessed 3 November 2005).

10 The members of the South Pacific Regional Environment Programme are: American Samoa, Australia, Cook Islands, Federated States of Micronesia, Fiji, France, French Polynesia, Guam, Kiribati, Marshall Islands, Nauru, New Caledonia, New Zealand, Niue, Northern Marianas, Palau, Papua New Guinea, Pitcairn 
of resources differ among PICs and must be considered along with the geographic diversity of the islands, ranging from low-lying atolls to high islands of volcanic origin. National priorities in ocean management differ as a result, despite the existence of common issues. PIROP is thus envisaged to provide a template that PICs could adopt and modify when developing their own national ocean policies. With rapid population growth in most PICs and the changing aspirations of Pacific Islanders as a result of their participation in the cash economy, there is now a collective awareness of the need to address pressing issues that have become common to all PICs. Unsustainable use of fisheries, habitat degradation, pollution of coastal waters from land-based as well sea-based sources, waste management, climate change, sea level rise and threats due to invasive species are examples of such common issues that are to be examined under a regional ocean policy.

The Policy itself is articulated around five guiding principles: 1-improving our understanding of the ocean; 2-sustainably developing and managing the use of ocean resources; 3-maintaining the health of the ocean; 4-promoting the peaceful use of the ocean; 5-creating partnerships and promoting cooperation. Strategic actions have been proposed for each principle that will be examined here along with implementation issues.

\section{IMPROVING OUR UNDERSTANDING OF THE OCEAN}

Given the financial costs and limited success of purely scientific approaches to resource management in the region, a precautionary approach enhancing the role of customary resource owners and traditional knowledge is advocated. The Samoan village fisheries by-laws can be seen as a model in this respect, ${ }^{11}$ and the extent to which this model is replicable in PICs with different structures of traditional authority such as Melanesia would need to be tested. This strategy of comanagement is to be pursued in parallel with improving access to scientific information related to ocean and coastal processes and ecosystems as a means to support decision-making. Partnerships between international and regional organisations, the public and private sectors will be required to implement this strategic action. Capacity building in enhancing knowledge management is to be addressed by establishing a regional network and procedures for information and data collection, maintenance and sharing and for coordination of research. It is worth noting that such procedures are already in place for managing tuna resources in the region but need further elaboration under the new WCPFC. The network of locally managed marine areas in the Western Pacific is another

Island, Samoa, Solomon Islands, Tokelau, Tonga, Tuvalu, United Kingdom, United States of America, Vanuatu, and Wallis and Futuna.

11 Village Fisheries By-laws are village rules that have been prepared in accordance with the provisions of the Fisheries Act 1988 (Samoa) and that are accorded legal recognition in the courts of law. The By-laws can cover any measure which assists in the management and conservation of fisheries resources. There are currently 57 village communities that have already put in place Fisheries By-laws in Samoa. For more information see: Ueta Fa'asili and Autalavou Tava Review of the Village Fisheries Management Plan of the Extension Program in Samoa (Field Report Number 7, Secretariat of the Pacific Community, Noumea, 2001). 
illustration of a systematic approach to the collection and sharing of information in order to determine the conditions in which locally managed marine areas work best in practice across different sites. ${ }^{12}$ Yet access to the internet remains difficult for communities in remote areas, which prevents effective use of the network's website and discussion forum.

\section{SUSTAINABLY DEVELOPING AND MANAGING THE USE OF OCEAN RESOURCES}

To be sustainable, development and management of coasts and the ocean must be integrated, precautionary and ecosystems-based. Engaging all stakeholders, including local communities, in resource management decision-making is an element central to the implementation of this principle. It must be considered as part of the need to ensure equitable sharing of resource access and benefits at local, national and regional levels. At the regional level, PICs are currently receiving less than 3 per cent of the gross revenue of tuna fished from their waters with estimated total access fees of US\$60 million for 1999. ${ }^{13}$ Therefore PICs need to explore more suitable ways of getting a better return from foreign access granted to their tuna fisheries. ${ }^{14}$ Strategies to maximise economic returns from the fishery need to be developed while also ensuring that harvesting remains below the maximum sustainable yield - harvesting above this level would present risks of over-exploitation given the poor enforcement of regulations and the lack of information to determine what the maximum sustainable yield is. Domestication of the tuna industry is another option for getting the full benefit out of the tuna resources. This will require the acquisition of competitive ships, extensive training of local officers and crew, and the upgrading of landing facilities. Such capacitybuilding represents a long-term commitment that has been acknowledged by forum participants. However, almost all the public fishing ventures initiated by PICs since the early 1990s have failed financially, giving rise to the following question: how should fishing revenue be invested so as to maximise sustained economic development? ${ }^{15}$

At the local and national levels, equitable access to resources and sharing of benefits require the establishment and protection of traditional knowledge and intellectual property rights. At present, PICs do not have adequate legislation to regulate bioprospecting nor to provide means of obtaining financial benefits (such as royalties) for the commercialisation of products derived from the use of their genetic resources. Existing intellectual property rights have a limited life, give priority to

12 See LMMA Network <http://www.lmmanetwork.org> (last accessed 3 November 2005).

13 R Gillett and others Tuna: a Key Economic Resource for the Pacific Islands (Asian Development Bank, Manila, 2001).

14 It is expected that the strengthening of institutional arrangements under the new WCPFC will enable access fees to be raised from 3 per cent to 10 per cent of gross revenue. This would increase revenue from access fees to nearly US\$400 million.

15 For possible options to this issue, see M Pretes and E Petersen "Rethinking Fisheries Policy in the Pacific" (2004) 28 Marine Policy 297. 
individual ownership and impose strict interpretations of invention. This is in contrast with traditional knowledge that is characterised by collective ownership held in perpetuity, but subject to change over time. The Secretariat of the Pacific Community and the Pacific Islands Forum Secretariat in partnership with UNESCO are currently working towards establishing legal protection of traditional knowledge through a regional model law. This model law may be used to protect traditional knowledge and other marine-related intellectual property from unauthorised exploitation. Traditional fishing techniques and traditional uses of marine resources for specific purposes such as healing may be examples of knowledge currently not protected by law. Countries wishing to enact the model law are free to adapt its provisions in accordance with their national needs.

Mechanisms that promote the use of traditional knowledge to inform management and its integration with other information sources will also have to be developed. Social, environmental and cultural impacts of significant policies and development initiatives will have to be assessed prior to their implementation. At present, mechanisms such as environmental impact assessments (EIAs) are not systematically in place throughout the region. Where EIAs are mandatory, the process often presents significant flaws preventing informed decision-making and consideration of possible alternatives. In addition, socio-economic valuation and assessment of resources as well as biological processes and pollution are not included as a legal requirement in most of the EIAs undertaken in the region.

\section{MAINTAINING THE HEALTH OF THE OCEAN}

This principle requires the preservation of ecosystem integrity and the minimisation of the harmful impacts of human activities. Biodiversity conservation is to be enhanced at local, national and regional levels by establishing networks of marine protected areas that are representative of the coastal and marine ecosystems present in the region. This strategic action extends to the high seas and offshore fisheries. For example, research is currently undertaken by the author on the identification of potential marine reserves in the Western and Central Pacific Ocean as a tool for managing tuna stocks. ${ }^{16}$ Candidate areas identified in the course of this research will be proposed to the members of the new WCPFC Commission for designation.

Preserving ecosystem integrity also means that national controls on the introduction of alien species must be enforced and the capacity to prevent, detect, monitor and respond to invasive alien species needs to be enhanced. Environmental management of ports, planning and response to marine spills are also capacity-building issues that need to be addressed. EIA legislation has already been identified as a tool for minimising the impacts of development activities. The relevance of EIA legislation might be considered here in the broader context of a need for adopting an integrated

16 See Laurence Cordonnery, East-West Center (cordonn_1@eastwestcenter.org) and Patrick Lehodey, Fisheries Scientist at the Secretariat for the Pacific Community (PatrickL@spc.int) for more information on their research project on the "Potential Impacts and Relevance of Marine Reserve Areas on Tuna Stocks and Fisheries in the Tropical Pacific Ocean". 
coastal management strategy for each PIC. At the regional level, an annual assessment of marine pollution issues is advocated to identify the various sources of marine pollution (from marine to land-based sources) and assess their respective impacts upon the marine environment. A regional Global Programme of Action for the Protection of the Marine Environment from Land-Based Activities needs to be established in order to increase national capacity to address monitoring, enforcement and clean-up of land-based pollution. This issue has not yet been addressed despite having important environmental implications on both fisheries and coastal environments, both locally and regionally. The impacts of mining discharges released into the Fly River in Papua New Guinea on the Torres Strait and the Great Barrier Reef in Australia are typical of the possible transboundary nature of land-based sources of marine pollution. The Ok Tedi copper mine is situated in the headwaters of the Ok Tedi, which is a tributary of the Fly River. The river system, with its huge estuary and massive flood plains, lakes and tributaries, supports one of the richest arrays of fish, aquatic and wetland fauna in the Pacific region. An average of 90 million tonnes of tailings and mine-induced erosion are discharged to the Ok Tedi each year from the Ok Tedi mine. About 50 million tonnes of this reaches the Fly River.

\section{PROMOTING THE PEACEFUL USE OF THE OCEAN}

In order to discourage illicit and criminal activities that contradict national, regional and international agreements, PICs have to exercise control and enforcement over their maritime zones. Maritime boundary delimitation and the settlement of disputes are to be addressed as prerequisites. Some PICs might be able to claim continental shelf-extension, such as Federated States of Micronesia, Papua New Guinea, Fiji, Solomon Islands and Tonga. These countries have little marine scientific research capacity of their own and are reliant on regional assistance from the South Pacific Applied Geosciences Commission for the delineation of potential continental shelf extension, which is geologically and legally complex. Lack of consistency between national legislation and international law needs to be addressed. This process has already begun, with the enactment of new fisheries legislation encompassing resource conservation issues and the adoption of national tuna management plans in most PICs. Compliance with international agreements needs to be strengthened, while monitoring and enforcement mechanisms already in place for fishing activities need to be fully implemented. For instance, a vessel monitoring system is part of the minimum terms and conditions for gaining fisheries access in any of the FFA member states' exclusive economic zones, but this requirement has yet to be implemented in some member countries. Collaboration with shipping and fishing nations as well as naval powers is to be sought. Australia, New Zealand and France have already concluded a number of bilateral arrangements with PICs for the surveillance of their maritime zones. The geographical coverage of such arrangements would need to be extended and the involvement of other naval powers to be sought.

\section{CREATING PARTNERSHIPS AND PROMOTING COOPERATION}

According to this principle, capacity building for improving ocean governance is to be achieved through partnerships and cooperation in the areas of security, monitoring, enforcement and the 
sustainable use of resources. Capacity-building is a major issue for PICs and improved ocean governance in these areas is highly dependent on partnerships and cooperation with donor countries and metropolitan powers. This realisation explains why PIROP was presented at the 2002 World Summit on Sustainable Development in Johannesburg as a partnership initiative on Small Islands Developing States. ${ }^{17}$ However, increasing the level of partnerships and cooperation might be difficult as some aid donors are also naval powers or fishing nations in the region, thus pursuing short-term as well as long-term interests that may not always coincide with the strategic actions advocated in the Policy. The trans-boundary movement of hazardous wastes such as plutonium illustrates such divergences of interests between the aid-donor countries involved in this trade, namely the United Kingdom, France and Japan and PICs whose legal positions range from seeking exclusion of the ship's route from EEZs to advocating a strict liability regime in case of an accident. On the other hand, donor countries involved in this trade maintain that there is no need for such a strict liability regime, and that the freedom of navigation should not be restrained.

In other instances partnerships and cooperation seem achievable, particularly when it comes to learning from past experience in the implementation of national ocean policies, as in the case of Australia. Some opportunities for cooperation in the management of inshore marine resources remain untapped, particularly regarding the transfer of technology and of research methodology from the French Pacific Territories whose linguistic and political isolation explains the absence of substantial partnerships with PICs until now. Regarding the management of tuna resources, cooperation with DWFNs may prove difficult, particularly when determining the allocation of total allowable catches in relation to gear type within the new convention area of the WCPFC. Similarly, the regulation of high seas fishing within the convention area and the implementation of the compatibility requirement between in-zone and high seas management measures remain uncertain. In so far as security is concerned, the international focus on the prevention of terrorism, and in particular the Proliferation Security Initiative, ${ }^{18}$ may provide some opportunities for PICs to enhance their maritime surveillance capacity through cooperation. This, in turn, might increase the leverage of PICs as a regional power bloc and give rise to trade-offs with the United States.

\section{CONCLUSION}

PICs have been visionary on a number of occasions related to ocean governance in the past, from their support to extended coastal state jurisdiction during negotiations on the United Nations Convention on the Law of the Sea (UNCLOS) to the more recent adoption of a regional approach to

17 Partnership initiatives presented at the Johannesburg Summit are to strengthen the implementation of Agenda 21 and related international instruments. Partnerships are voluntary multi-stakeholder initiatives, intended to be a complement and not a substitute to these commitments. See generally Marion Wilson "The New Frontier in Sustainable Development: World Summit on Sustainable Development Type II Partnerships" (2005) 36 VUWLR 389.

18 See "The Proliferation Security Initiative" <http://usinfo.state.gov> (last accessed 3 November 2005). 
managing tuna resources in the wake of the 1995 Agreement on the UNCLOS provisions relating to the conservation and management of highly migratory fish stocks. PIROP demonstrates, at least on paper, the pro-activeness of PICs as a united voice advocating an improved management of the largest and last commercially sustainable ocean on earth. Within the region, political leadership and the willingness to commit and raise adequate resources will be essential if the foreseeable implementation difficulties outlined in this article are to be overcome. This challenge will determine whether the Policy can be used as a model in ocean governance as it promises to be. For regional powers within the Pacific Rim who were not part of the inception and endorsement phases of the PIROP process, their commitment to PIROP will be determined by their willingness to act as partners and to cooperate with PICs in the implementation process. 
